\title{
Trends in hospital discharges for intestinal infectious disease in infants in Argentina, 2005-2013
}

\author{
Juan I. Degiuseppe, Magister ${ }^{a}$
}

\begin{abstract}
Introduction. Acute diarrhea is one of the most serious public health problems in developing countries because it is generally associated with unfavorable living conditions. The objective of this study was to analyze trends in hospital discharges for intestinal infectious disease in children under age 5 recorded in official public hospitals from Argentina in the 2005-2013 period. Population and methods. This was an ecological, time-series study based on data provided by the Health Statistics and Information Department, at a national and regional level. Specific hospital discharge rates were estimated, and seasonal behavior and trends were analyzed in relation to this event.

Results. In Argentina, 2521729 patients under age 5 were discharged in this period; of these, $9.0 \%$ were diagnosed with intestinal infectious disease. Children under age 1 accounted for a third of hospitalizations; two annual peaks (summer and winter) were observed in the seasonality analysis. Overall, a downward trend was observed, with a mild increasein the 2007-2009 period. Rateswereup to 3 or 4 times higher in Northwest and Northeast Argentina than in the Pampa region.

Conclusions. Hospital discharges for intestinal infectious disease in the public subsector account for approximately $10 \%$ of all discharges of children under age 5. This event shows a seasonal pattern, with a slightly downward trend over the past years in spite of its heterogeneous distribution across the different Argentine regions.

Key words: diarrhea, Argentina, hospitalization,
\end{abstract} infants.

http:/ / dx.doi.org/10.5546/ aap.2017.eng.350

To cite: Degiuseppe JI. Trends in hospital discharges for intestinal infectious disease in infants in Argentina, 2005-2013. Arch Argent Pediatr 2017;115(4):350-356.

\section{INTRODUCTION}

Acute diarrhea is one of the main causes of morbidity and mortality in children under age 5 worldwide. Together with pneumonia, these diseases have the greatest impact in this age group after perinatal conditions. ${ }^{1,2}$ In addition, the impact of diarrheaassociated morbidity and mortality shows an heterogeneous distribution depending on the socioeconomic and cultural level of each country. ${ }^{2}$ Diarrhea-associated severe cases (requiring hospitalization) and fatalities are generally related to different factors: inadequate health/hygiene conditions, lack of education and preventive information for parents, and difficulties accessing health care services for a timely and adequate management.,

In Latin America, it is estimated that diarrhea causes approximately 248 million acute episodes and 11000 deaths per year in children under age $5 .^{2}$ In Argentina, 1-1.2 million cases of acute diarrhea are reported annually; approximately $50 \%$ of these occur in children under age $5 .{ }^{5}$ This disease results in 100 deaths per year in average; $1.2 \%$ in this age group. ${ }^{6,7}$

Also in Argentina, trends in diarrhea-associated mortality rates showed a significant reduction as of the 1980s, following the introduction of therapy with oral rehydration salts. ${ }^{8}$ In addition, there is no updated information on hospital discharges for this cause.

The objective of this study was to analyze trends in hospital discharges for intestinal infectious disease in children under age 5 in official public hospitals from Argentina in the 20052013 period.

\section{POPULATION AND METHODS}

This study was designed based on a mixed, ecological, time trend approach. Analysis units included in the study were the 24 jurisdictions of Argentina. For regional analysis purposes, data were grouped into the 5 Argentine economic regions: Cuyo, Northeast Argentina (NEA), Northwest Argentina (NOA), Pampa, and Patagonia. ${ }^{9}$ 


\section{Hospital discharges}

The hospitalization concept was operationalized using the total number of hospital discharges of children under age 5 and, specifically, the number of hospital discharges of children in the same age group diagnosed with certain intestinal infectious diseases as the main cause for hospitalization (A00-A09 code as per the International Statistical Classification of Diseases and Related Health Problems $)^{10}$ as recorded in the annual report on hospital discharges from official hospitals by diagnosis published by the Health Statistics and Information Department (Dirección de Estadísticas e Información en Salud, DEIS). This report provides data on hospital discharges recorded in every official health care facility (at a national, provincial or municipal level). Hospital discharges included in the study were those occurred between January $1^{\text {st }}, 2005$ and December $31^{\text {st }}, 2013$ in the public subsector, disaggregated by month. Hospital discharges occurred in other countries or in an unspecified province were excluded.

First of all, hospital discharge rates were estimated for patients under age 5 and diagnosed with certain intestinal infectious diseases, corresponding to each province, and using the ratio between the number of hospital discharges for such diagnosis as the main cause and the population in this age group for each year. These data were then disaggregated into specific hospital discharge rates for two age ranges: under age 1 and 1 to 4 years. The denominator for the first age group was the number of live births; and for the second, the population of children aged 1-4 years. Population data were obtained from vital statistics annual reports prepared by the DEIS. ${ }^{6,711-17}$ Province data were grouped to perform regional analyses; in turn, these data were then combined for the national analysis.

The statistical analysis of variations in trends was done using the Mann-Kendall test with the Microsoft Office Excel XLSTAT 2016.07 complement. A $p$ value $<0.05$ (significance level) was considered an alternative hypothesis (presence of a negative trend in the series).

\section{Seasonality study}

The total number of hospital discharges of patients diagnosed with certain intestinal infectious diseases in each province was considered, disaggregated by month for the 2005-2013 period. For standardization purposes, the month during which the hospital discharge occurred was taken into account.

\section{Ethical aspects}

The study used data from secondary sources so it was not necessary to obtain an informed consent. Besides, data were managed in agreement with the Protection of Personal Information Act (National Law no. 25326).

\section{RESULTS \\ Overall event description}

At the time of database consolidation, the DEIS recommendations regarding the lack of information or coverage difficulties in certain jurisdictions were taken into consideration. Overall, it is estimated that annual data available for national and regional analyses account for more than $75 \%$ of data coverage.

TABLE 1. Distribution of hospital discharges for intestinal infectious disease in children under age 5. Argentina, 2005-2013

\begin{tabular}{|c|c|c|c|}
\hline Year & Total hospital discharges ua $5^{a}$ & HDua5 $^{\text {b }}$ & HDua5/total hospital discharges ua5 (\%) \\
\hline 2005 & 286062 & 27606 & 9.7 \\
\hline 2006 & 291618 & 22043 & 7.6 \\
\hline 2007 & 295432 & 24995 & 8.5 \\
\hline 2008 & 276378 & 26461 & 9.6 \\
\hline 2009 & 273687 & 27518 & 10.1 \\
\hline 2010 & 277645 & 26513 & 9.5 \\
\hline 2011 & 269012 & 24607 & 9.1 \\
\hline 2012 & 267015 & 24358 & 9.1 \\
\hline 2013 & 284880 & 26539 & 9.3 \\
\hline TOTAL & 2521729 & 230640 & 9.2 \\
\hline
\end{tabular}

Source: Developed based on data provided by the Health Statistics and Information Department.

a ua5: children under age 5 .

${ }^{\mathrm{b}}$ HDua5: hospital discharges for intestinal infectious disease in children under age 5. 
In the 2005-2013 period in Argentina, 2521729 hospital discharges were recorded in public hospitals in children under age 5; of these, 230640 $(9.2 \%)$ were diagnosed with intestinal infectious disease (Table 1). The largest number of hospital discharges for intestinal infectious disease in the studied group occurred in 2005 (27 606 hospitalizations). Overall, hospital discharges for this cause ranged between 22000 and 28 000, with an approximate arithmetic mean of 25627 and a median of 26461 hospital discharges (2008). The overall ratio of hospital discharges for intestinal infectious disease was not similar once data were disaggregated by region. In the NOA, NEA, and Cuyo regions, intestinal infectious diseases were the cause of $12-14 \%$ of hospital discharges in children under age 5. By contrast, in the Pampa and Patagonia regions, this event accounted for approximately $7 \%$ of hospital discharges.

In terms of distribution by age group, $36.0 \%$ of hospital discharges were recorded in children under age 1 ; this ratio was observed throughout the entire series. Taking a more thorough look at the 1-4 year-old age group, the 1 year-old group accounted for approximately $60 \%$ of these hospital discharges.

\section{Trends}

Overall, the trend in the rate of hospital discharges for intestinal infectious disease in children under age 5 (RHDua5) decreased, although a slight increase was observed in the 2007-2009 period (Table 2). In addition, towards the end of the study, the RHDua5 returned to the

TABLE 2. Rate of hospital discharges for intestinal infectious disease in children under age 5. Argentina, 2005-2013

\begin{tabular}{lcc}
\hline & RHDua5 $^{\mathbf{a}}$ & Inter-annual variation \\
\hline $\mathbf{2 0 0 5}$ & 9.0 & $-21.1 \%$ \\
$\mathbf{2 0 0 6}$ & 7.1 & $+8.4 \%$ \\
$\mathbf{2 0 0 7}$ & 7.7 & $+3.9 \%$ \\
$\mathbf{2 0 0 8}$ & 8.0 & $+5.0 \%$ \\
$\mathbf{2 0 0 9}$ & 8.4 & $-7.1 \%$ \\
$\mathbf{2 0 1 0}$ & 7.8 & $-2.6 \%$ \\
$\mathbf{2 0 1 1}$ & 7.6 & $-1.3 \%$ \\
$\mathbf{2 0 1 2}$ & 7.5 & $-5.3 \%$ \\
$\mathbf{2 0 1 3}$ & 7.1 & \\
\hline
\end{tabular}

Source: Developed based on data provided by the Health Statistics and Information Department.

a RHDua5: rate of hospital discharges for intestinal infectious disease in children under age 5. lowest values in this series. In the beginning of the study period, the RHDua5 was 9.0/1000 children under age 5 . In 2013, it reduced by $21.1 \%$, until reaching 7.1/1000 children under age 5. Besides, the $p$ value was 0.227 , so the null hypothesis could not be ruled out (no trend observed in the analyzed series).

Once data were disaggregated into rates corresponding to the under age 1 and 1-4 year-old subpopulations, the same behavior was observed as in the overall trend; however, the rate was higher in the under age 1 group compared to the group aged 1-4 years over the entire study period (Figure 1).

In the NOA region, the RHDua5 was the highest across all regions. The NOA showed the same downward trend as that observed at a national level. The lowest rate was recorded in 2012, which increased the following year (Figure 2). In the NEA region, the lowest rate was recorded in 2006 (10.2/ 1000 children under age 5), but after a relatively stable period (2007-2012), it increased towards the end of the study period. In the Pampa region, the lowest rate was observed in 2013. The overall trend in this region declined, but it was low. In the Cuyo region, the lowest rate was recorded in 2006 but, surprisingly, it increased significantly in 2008 (15.7/ 1000 children under age 5). Following such marked increase, a downward trend was observed once again. In the Patagonia region, the lowest rates were seen in 2005 and 2006; subsequently the trend went upwards up to 2009, once the baseline value was exceeded. In the last two years of the study, the trend decreased once again. It is worth noting that in all regions, the rates in the under age 1 group were higher than in the group aged 1-4 years (data not shown).

To analyze the interregional relative risk, the ratio between the RHDua5 and that of the Pampa region was estimated, which was taken as reference because it showed the lowest value (Figure 2). The ratios were up to 2.5-3 times higher in the NOA and NEA regions over the entire study period. The Patagonia region showed the greatest similarity to the reference region. Besides, it was observed that, except for the Cuyo region, the relative risks in each region remained relatively consistent.

\section{Seasonality}

The analysis revealed a seasonal behavior. Overall, two peaks were observed each year: one between November and February, and another 
between June and August (Figure 3). In addition, these peaks did not have the same size over the entire study period. This was only observed in 2006 and 2008. In 2005, the peak in the summer months was greater than that in the winter months. Towards the end of the study period (2009-2013), the peak in the cold months was higher than that observed in the first months of the year. In general, no critical differences were observed in the seasonal pattern between the under age 1 group and the group aged 1-4 years.

\section{DISCUSSION}

Acute diarrhea is one of the most serious public health problems in developing countries because it is generally associated with unfavorable living conditions. In Argentina, hospital discharges for intestinal infectious disease accounted for approximately $9 \%$ of all discharges in children under age 5 . In addition, the highest burden of this disease was observed in children younger than 2 years (approximately 75\% of hospital discharges).

FIGURE 1. Trends in the rate of hospital discharges for intestinal infectious disease in children under age 5, under age 1, and aged 1-4 years (per 1000 children under age 5, live births, and children aged 1-4 years, respectively). Argentina, 2005-2013

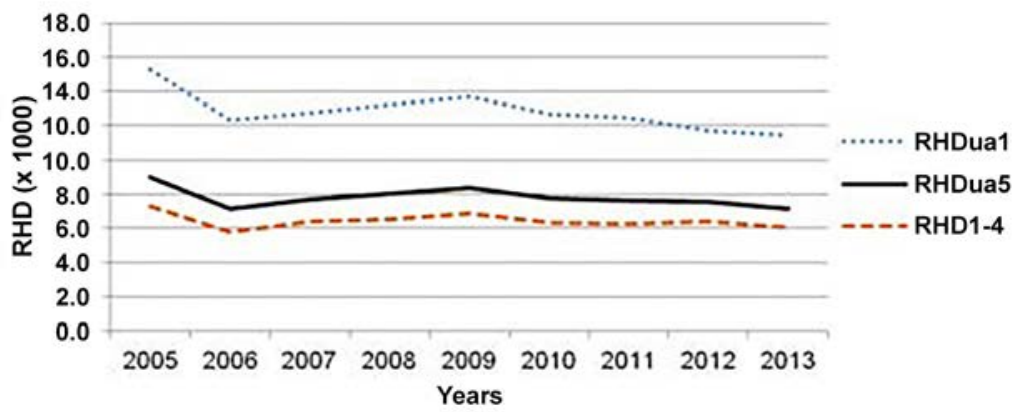

Source: Developed based on data provided by the Health Statistics and Information Department.

RHD: rate of hospital discharges for intestinal infectious disease.

RHDua5: rate of hospital discharges for intestinal infectious disease in children under age 5.

RHDua1: rate of hospital discharges for intestinal infectious disease in children under age 1.

RHD1-4: rate of hospital discharges for intestinal infectious disease in children aged 1-4 years.

FIGURE 2. Trends in the rate of hospital discharges for intestinal infectious disease in children under age 5 (per 1000 children under age 5). Argentine regions, 2005-2013

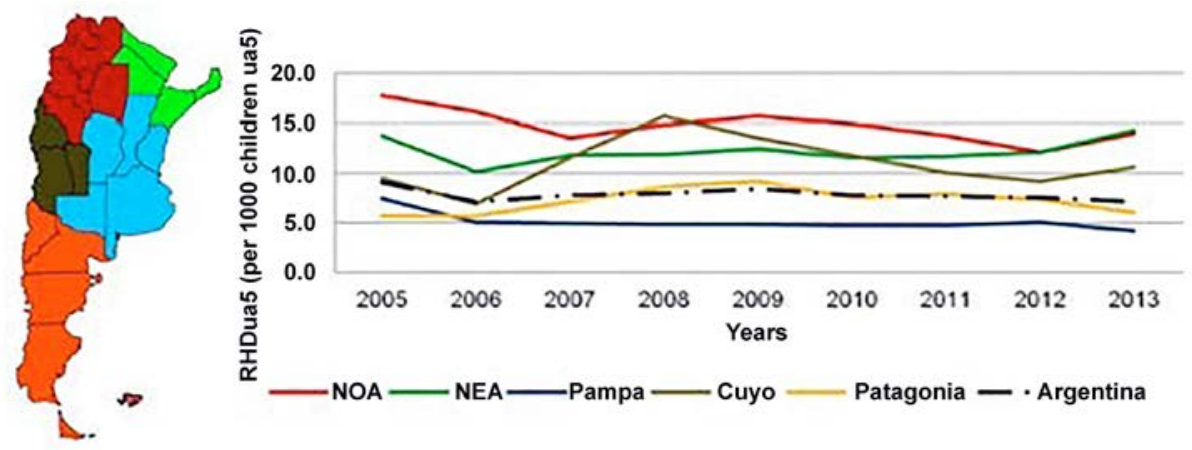

Source: Developed based on data provided by the Health Statistics and Information Department.

RHDua5: rate of hospital discharges for intestinal infectious disease in children under age 5; ua5: children under age 5;

NOA: Northwest Argentina; NEA: Northeast Argentina. 
The RHDua5 showed a slightly downward trend, but it did not reach statistical significance. Regional trends showed the same behavior observed at a national level, but at different sizes and specific ranges. Rates were up to 3 or 4 times higher in the NOA and NEA than in the Pampa region. Therefore, no homogeneity was observed in the distribution of hospital discharges for intestinal infectious disease in Argentina. The greatest variation occurred in the Cuyo region. This could not be explained by merely looking at data. Although the upward trend may be validated by the observation of the same behavior in most regions, the size of the increase is striking. Also considering that in this period there were no major limitations in relation to data coverage, it is necessary to pose the hypothesis of a regional outbreak or reporting-related events.

In terms of seasonality, two annual peaks were observed: one in the summer months (December-March) and another in the cold months (June-August). It is worth noting that a change was observed in the ratio of seasonal peaks. This may be connected to factors related to the etiology of diarrhea and improvements in health/hygiene conditions, both at an individual and a community level. Given that bacterial diarrhea more often occurs in the summer months, the population's healthier conditions result in a decrease in this type of pathology. In addition, these improvements do not have a fundamental impact on the reduction of virusrelated hospitalizations and deaths, frequent in the cold months, so the peak during this season is expected to remain over time. ${ }^{18}$

The overall observation regarding trends in hospital discharges for intestinal infectious disease is similar to that of mortality for intestinal infectious disease analyzed by Bossio et al. ${ }^{8}$ Therefore, this study may validate observed results and somehow provide evidence that both events (hospitalizations and deaths), although obtained from different sources of data, are connected to the same disease and may be used interchangeably to monitor trends in severe cases.

In Latin America, there are now more studies assessing trends in severe acute diarrhea because of assessments regarding the impact of introducing the rotavirus vaccine in national immunization schedules. ${ }^{19-22}$ All studies have demonstrated similar results: significant downward trends (approximately 40\%), notably in the cold months. ${ }^{23}$ Considering that, in Argentina, the rotavirus vaccine was introduced in the national immunization schedule in 2015, this study is an account of the pre-immunization scenario for this event. Further studies are needed to assess whether the impact of this intervention has been similar in other countries of this region.

Although the use of secondary data makes it possible to conduct low cost and feasible studies, it is very important to take this study's limitations into account. First of all, given the instrument's defects, there is a likelihood of bias related to the classification of the main cause for hospital discharge. In addition, using the same coding system is useful to compare data at a local, national, and international level. Secondly, in some jurisdictions, data coverage was low or even missing for some years. Therefore, it is critical to consider that every analysis done in relation to this study was completed under the assumption that under-coverage was random, not biased. Besides, as the risks for hospitalization due to

FIGURE 3. Number of monthly hospital discharges for intestinal infectious disease. Argentina, 2005-2013

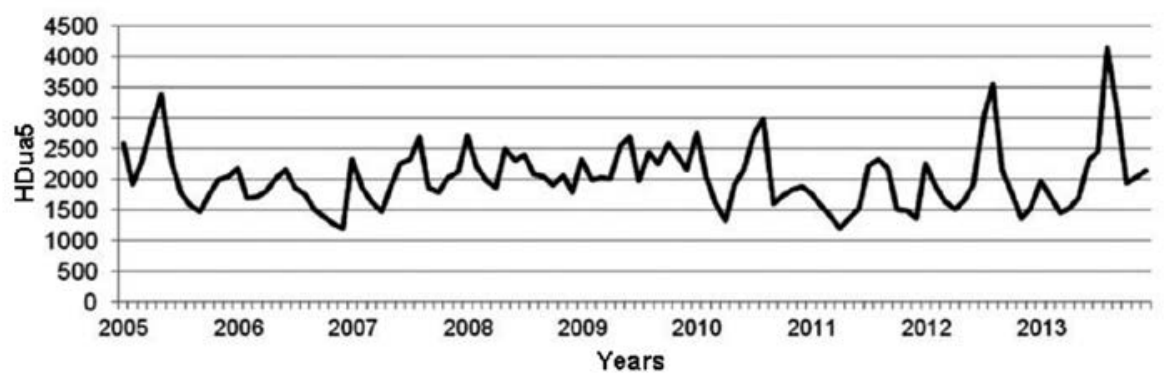

Source: Developed based on data provided by the Health Statistics and Information Department.

HDua5: hospital discharges for intestinal infectious disease in children under age 5. 
intestinal infectious disease are heterogeneous across the different Argentine regions, it is highly likely that hospital practices and admission policies may also differ. Therefore, in a setting where official facilities account for $45-50 \%$ of the health sector ${ }^{24}$ caution should be exercised not to estimate the burden of this disease globally because it would mean assuming that the semipublic and private subsectors may behave in the same manner.

Hospitalizations and deaths caused by acute diarrhea are a complex problem permeated by multiple determinants at an individual and community level; acute diarrhea prevention and management are still a challenge for actors involved in the decision-making process. Although a reduction in hospital discharges for this cause has been observed in this study, its relevance is still limited. Monitoring the RHDua5 is not only a reflection of the problem that acute diarrhea means in Argentina. Considering that this is an avoidable event, it is also useful as an indirect measure of quality and accessibility to primary health care (PHC) strategy. ${ }^{25}$ Therefore, teams working at PHC centers play a critical role in the coordination of acute diarrhea prevention and management activities between the community and municipal authorities. These activities require support from macro-policies that enable the timely intervention of primary health care providers together with adequate nutrition, immunization, and hygiene/health conditions, especially among children younger than 2 years old.

\section{CONCLUSIONS}

In Argentina, hospital discharges for intestinal infectious disease recorded in the public subsector account for approximately $10 \%$ of all discharges of children under age 5 . This event shows a seasonal pattern, with a slightly downward trend over the past years in spite of its heterogeneous distribution across the different Argentine regions.

\section{Acknowledgments}

I would like to thank Juan Andrés Stupka and Adrián Santoro for their valuable collaboration with this manuscript.

\section{REFERENCES}

1. Liu L, Johnson H, Cousens S, et al. Global, regional and national causes of child mortality: an updated systematic analysis for 2010 with time trends since 2000. Lancet 2012;379(9832):2151-61.
2. Walker C, Rudan I, Liu L, et al. Global burden of childhood pneumonia and diarrhoea. Lancet 2013;381(9875):1405-16.

3. Fondos de las Naciones Unidas para la Infancia/ Organización Mundial delaSalud. Diarrhoea: why children are still dying and what can be done. Nueva York; 2009 [Accessed on: March 10 th, 2016]. Available at: http:// whqlibdoc.who.int/ publications / 2009/9789241598415_ eng.pdf?ua $=1$.

4. Afazani A, Beltramino D, Bruno M, et al. Diarrea aguda en la infancia. Actualización sobre criterios de diagnóstico y tratamiento [Consenso nacional]. Buenos Aires: Sociedad Argentina dePediatría; 2004 [Accessed on: March 10 ${ }^{\text {th }}, 2016$ ]. Availableat:http:/ / www.sap.org.ar/docs/profesionales/ consensos/diarreagu.pdf.

5. Ministerio de Salud. Situación epidemiológica actual de las diarreas en Argentina. Boletín integrado de vigilancia 2012;128(SE 28):10-24. [Accessed on: January $24^{\text {th }}$, 2017]. Available at: http://www.msal.gob.ar/ images / stories / epidemiologia / boletines-online / BoletinIntegradoDeVigilanciaVersion_N128-SE28/.

6. Dirección de Estadísticas e Información de Salud. Estadísticas vitales. Información básica - año 2012 [online periodic publication]. Buenos Aires; 2013. [Accessed on: January $8^{\text {th }}$, 2016]. Available at: http:/ / www.deis.msal.gov. ar/wp-content/uploads/2016/01/Serie5Nro56.pdf.

7. Dirección de Estadísticas e Información de Salud. Estadísticas vitales. Información básica - año 2013 [online periodic publication]. Buenos Aires; 2014. [Accessed on: January $8^{\text {th }}$, 2016]. Available at: http:/ / www.deis.msal.gov. ar/wp-content/uploads/2016/01/Serie5Nro57.pdf.

8. Instituto Nacional de Enfermedades Respiratorias $\square$ Dr. Emilio Coni $\square$. Mortalidad por enfermedades infecciosas intestinales en menores de 5 años: Argentina $\square$ Actualización 2014 [Internet]. Santa Fe; 2016. [Accessed on: June 10 ${ }^{\text {th }}$, 2016]. Availableat:http: / / www.anlis.gov.ar/iner/wp-content / uploads / 2016/04/Boletin-Actualizacion-Mortalidad-porDiarrea-en-Menores-de-5-ano-2014.pdf.

9. Instituto NacionaldeEstadísticasy Censos. Censo Nacionalde Población, Hogaresy Viviendas 2010[Internet]. Buenos Aires; 2011. [Accessed on: March 10 ${ }^{\text {th }}$, 2016]. Available at: http:/ / www.indec.gov.ar/nivel4_default.asp?id_tema_1=2\&id_ tema_2=41\&id_tema_3=135.

10. Organización Mundial de la Salud. International Statistical Classification of Diseases and Related Health Problems. 10th revision [Internet]. Ginebra, OMS: 1992. [Accessed on: January $3^{\text {rd }}$, 2016]. Available at: http: / / www.cdc.gov / nchs/data/dvs/2006-Vol-I.pdf.

11. Dirección de Estadísticas e Información de Salud. Estadísticas vitales. Información básica - año 2005 [online periodic publication]. Buenos Aires; 2006. [Accessed on: January $8^{\text {th }}$, 2016]. Available at: http:/ / www.deis.msal.gov. ar/wp-content/uploads / 2016/01/Serie5Nro49.pdf.

12. Dirección de Estadísticas e Información de Salud. Estadísticas vitales. Información básica - año 2006 [online periodic publication]. Buenos Aires; 2007. [Accessed on: January $8^{\text {th }}$, 2016]. Available at: http:/ / www.deis.msal.gov. ar/wp-content/uploads/2016/01/Serie5Nro50.pdf.

13. Dirección de Estadísticas e Información de Salud. Estadísticas vitales. Información básica - año 2007 [online periodic publication]. Buenos Aires; 2008. [Accessed on: January $8^{\text {th }}$, 2016]. Available at: http:/ / www.deis.msal.gov. ar/wp-content/uploads/2016/01/Serie5Nro51.pdf.

14. Dirección de Estadísticas e Información de Salud. Estadísticas vitales. Información básica - año 2008 [online periodic publication]. Buenos Aires; 2009. [Accessed on: January $8^{\text {th }}$, 2016]. Available at: http:/ / www.deis.msal.gov. ar/wp-content/uploads / 2016/01/Serie5Nro52.pdf. 
15. Dirección de Estadísticas e Información de Salud. Estadísticas vitales. Información básica - año 2009 [online periodic publication]. Buenos Aires; 2010. [Accessed on: January $8^{\text {th }}$, 2016]. Available at: http:/ / www.deis.msal.gov. ar/wp-content/uploads/2016/01/Serie5Nro53.pdf.

16. Dirección de Estadísticas e Información de Salud. Estadísticas vitales. Información básica - año 2010 [online periodic publication]. Buenos Aires; 2011. [Accessed on: January $8^{\text {th }}, 2016$ ]. Available at: http:/ / www.deis.msal.gov. ar/wp-content/ uploads/2015/12/Serie5Nro54.pdf.

17. Dirección de Estadísticas e Información de Salud. Estadísticas vitales. Información básica - año 2011 [online periodic publication]. Buenos Aires; 2012 [Accessed on: January $\left.8^{\text {th }}, 2016\right]$. Available at: http:/ / www.deis.msal.gov. ar/wp-content/uploads/2016/01/Serie5Nro55.pdf.

18. Velázquez F, Garcia-Lozano H, Rodríguez E, et al. Diarrhea morbidity and mortality in Mexican children: impact of rotavirusdisease. Pediatr Infect Dis J2004;23(10Suppl):S149-55.

19. Esparza-Aguilar M, Bautista-Márquez A, GonzálezAndrade M, et al. Mortalidad por enfermedad diarreica en menores, antes y después de la introducción de la vacuna contra el rotavirus. Salud Pública Mex 2009;51(4):285-90.

20. Orozco M, Vasquez J, Pedreira C, et al. Uptake of rotavirus vaccine and national trends of acute gastroenteritis among children in Nicaragua. J Infect Dis 2009;200(Suppl 1): S125-30.

21. Do Carmo G, Yen C, Cortes J, et al. Decline in diarrhea mortality and admissions after routine childhood rotavirus immunization in Brazil: a time-series analysis. PLoS Med 2011;8(4):e1001024.

22. De Oliveira L, Giglio N, Ciapponi A, et al. Temporal trends in diarrhea-related hospitalizations and deaths in children under age 5 before and after the introduction of the rotavirus vaccine in four Latin American countries. Vaccine 2013;31(Suppl 3):C99-108.

23. Esparza-Aguilar M, Gastañaduy P, Sánchez-Uribe E, et al. Diarrhoea-related hospitalizations in children before and after implementation of monovalent rotavirus vaccination in Mexico. Bull World Health Organ 2014;92(2):117-25.

24. Organización Panamericana de la Salud. Salud en las Américas 2007: Volumen II - Países. Argentina. [Internet]. Washington;2007:38-61. [Accessed on: January 15 ${ }^{\text {th }}, 2016$ ]. Available at: http: / / www.bvs.hn/docum/ops/SA2007 / SAvol2esp/Argentina\%20Spanish.pdf.

25. Caminal Homar J, Sánchez E, Morales M, et al. Avances en España en la investigación con elindicador "Hospitalización por Enfermedades Sensibles a Cuidados de Atención Primaria". Rev Esp Salud Pública 2002;76(3):189-96. 